\title{
Model Sistem Penunjang Keputusan Untuk Menentukan Jurusan Calon Siswa Baru Menggunakan Metode Profile Matching Pada SMK XYZ
}

\author{
Agus Umar Hamdani*, Savira Aprilya \\ Fakultas Teknologi Informasi, Sistem Informasi, Universitas Budi Luhur, Jakarta, Indonesia \\ Email : 1,* agus.umarhamdani@ budiluhur.ac.id, ${ }^{2}$ svraprilya@gmail.com \\ Email Penulis Korespondensi: agus.umarhamdani@budiluhur.ac.id
}

\begin{abstract}
Abstrak-SMK XYZ adalah salah satu SMK yang berbasis teknologi yang berada di Jakarta Selatan. SMK tersebut memiliki beberapa jurusan yaitu Rekayasa Perangkat Lunak (RPL), Teknik Komputer Jaringan (TKJ) dan Multimedia (MM). Setiap tahun ajaran baru, calon peserta didik baru yang mendaftar semakin bertambah. Akan tetapi ada masalah yang dihadapi dalam proses pemilihan jurusan siswa, yaiu pengambilan keputusan yang kurang akurat, belum terdapatnya perankingan, pengambilan keputusan belum menggunakan metode dan masih menggunakan Microsoft excel sehingga membutuhkan waktu yang cukup lama dalam menentukan jurusan calon siswa. Tujuan penelitian ini adalah untuk membuat sistem penunjang keputusan yang diharapkan dapat membantu dalam menentukan jurusan yang tepat untuk siswa peserta didik baru di SMK XYZ yang sesuai dengan kriteria yang sudah ditetapkan oleh SMK XYZ. Penelitian ini menghasilkan sebuah sistem penunjang keputusan dengan menggunakan Metode Profile Matching sebagai metode untuk menentukan nilai akhir alternatif. Laporan yang dihasilkan oleh sistem ini adalah laporan nilai yang berisi nilai hasil perhitungan nilai-nilai siswa. Sistem penunjang keputusan ini dibuat dengan menggunakan MySQL sebagai database dan Microsoft Visual Studio 2008 sebagai tool pembuatan sistem. Dengan adanya sistem penunjang tersebut, maka dapat membantu staf kesiswaan dalam mengolah data dan pengambilan keputusan dalam rangka menentukan jurusan calon siswa baru
\end{abstract}

Kata Kunci: Sistem Penunjang Keputusan; Metode Profile Matching; Penentuan Penjurusan

\begin{abstract}
SMK XYZ is a Vocational School based on technology and located in South Jakarta. This school has several majors, namely Software Engineering (RPL), Network Computer Engineering (TKJ) and Multimedia (MM). Every new school year, new students of new students who register increases. However, there are problems encountered in the process of selecting student majors, namely inaccurate decision making, there is no ranking, decision making has not used the method and is still using Microsoft Excel, so it requires quite a long time in determining student majors. The purpose of this study is to create a decision support system that is expected to help in determining the right majors for new students in SMK XYZ in accordance with the criteria set by SMK XYZ. This research resulted in a decision support system using the Profile Matching Method as a method for determining alternative final values. Reports produced by this system are value reports that contain the values calculated by students' grades. This decision support system was created using MySQL as a database and Microsoft Visual Studio 2008 as a system creation tool. With this support system, it can help the student in processing data and decision making in order to determine student majors.
\end{abstract}

Keywords: Decision Support System; Profile Matching Method; Determination of Majors

\section{PENDAHULUAN}

Pengambilan keputusan adalah suatu pendekatan sistematis pada hakikat suatu masalah, pengumpulan faktafakta, penentuan yang matang dari alternatif yang dihadapi, dan pengambilan tindakan yang menurut perhitungan merupakan tindakan yang paling tepat [1]. Sistem pendukung keputusan adalah sistem informasi yang membantu untuk mengidentifikasi kesempatan pengambilan keputusan atau menyediakan informasi untuk membantu pengambilan keputusan [2]. SMK XYZ adalah lembaga pendidikan swasta yang berlokasi di Jakarta dan memiliki beberapa jurusan / program. Pemilihan jurusan adalah serangkaian kegiatan yang dilakukan untuk membantu calon siswa dalam menyalurkan dirinya ke dalam berbagai kegiatan sekolah sesuai dengan bakat dan kompetensi yang dimilikinya [3].

Penjurusan siswa ditentukan oleh bagian kesiswaan berdasarkan dari pilihan siswa saat melakukan pendaftaran dengan memberikan nilai hasil ujian nasional, tes potensi akademik dan mengisi angket jurusan yang diminati. Terdapat beberapa tahapan untuk menentukan jurusan seperti penginputan nilai ujian nasional yang sudah diberikan oleh calon siswa baru, lalu setelah itu diadakan tes penjurusan yang hasilnya akan ditambahkan dengan nilai ujian nasional untuk nantinya dilihat jurusan apakah yang sesuai untuk calon siswa baru tersebut. Namun saat ini perhitungan tersebut belum digunakan secara maksimal oleh staf kesiswaan dalam menentukan jurusan calon siswa baru. Staf kesiswaan masih menentukan jurusan calon siswa baru berdasarkan persepsinya pribadi. Dan juga semakin hari calon siswa baru yang mendaftar di SMK XYZ semakin banyak, data yang diolah juga lebih banyak dari tahun sebelumnya sehingga bisa terjadi human error pada bagian kesiswaan yang salah menentukan jurusan siswa. Oleh karena itu dibutuhkan sistem pendukung keputusan yang dapat melakukan perhitungan nilai, kemampuan serta minat yang dimiliki siswa untuk membantu menentukan jurusan yang tepat.

Sistem penunjang keputusan yang akan digunakan oleh bagian kesiswaan menggunakan metode Profile Matching. Metode profile matching atau pencocokan profil adalah metode yang sering digunakan sebagai mekanisme dalam pengambilan keputusan dengan mengasumsikan bahwa terdapat tingkat variabel prediktor 
yang ideal yang harus dipenuhi oleh subyek yang diteliti agar hasil ideal dapat ditentukan. Beberapa studi literatur yang menjadi rujukan penulis, antara lain : penelitian pertama yang membahas tentang sistem penunjang keputusan menggunakan metode Profil Matching untuk menyeleksi calon siswa baru di SMA Negeri 3 Garut [4], kemudian penelitian kedua yang membahas sistem penunjang keputusan menggunakan Profil Matching untuk menentukan pemilihan lokasi perumahan [5], dan penelitian ketiga yang membahas sistem penunjang keputusan menggunakan metode Profil Matching untuk memilih kandidat calon tenaga kerja [6].

Berdasarkan kondisi yang terjadi pada SMK XYZ dan hasil studi literature diatas, maka penulis melakukan penelitian untuk membantu SMK XYZ dalam menentukan jurusan calon siswa baru menggunakan metode Profil Matching.

\section{METODOLOGI PENELITIAN}

\subsection{Metode Profile Matching}

Metode Profile Matching atau sering disebut juga dengan metode gap, yaitu sebuah mekanisme pengambilan keputusan dengan mengasumsikan bahwa terdapat tingkat variabel prediktor yang ideal yang harus dimiliki oleh subyek yang dinilai [7]. Dalam proses profile matching, akan dilakukan proses pembandingan antara kompetensi individu ke dalam kompetensi standar, sehingga dapat diketahui perbedaan kompetensinya atau gap-nya. Semakin kecil gap yang dihasilkan, maka bobot nilainya semakin besar. Prosedur perhitungan dalam metode profile matching [8] dijelaskan sebagai berikut :

a) Menentukan Variabel / kriteria penilaian

Langkah pertama dalam menggunakan metode profile matching adalah menentukan variabel-variabel yang nantinya akan digunakan sebagai point untuk penilaian para calon peserta didik baru.

b) Pemetaan Gap Kompetensi

Gap yang dimaksud di sini adalah perbedaan/selisih value masing-masing aspek/atribut dengan value target. Contoh Perbedaan value profil siswa dengan value profil jurusan.

c) Pembobotan

Setelah diperoleh gap pada masing-masing siswa, setiap profil siswa diberi bobot nilai sesuai ketentuan pada tabel bobot nilai gap yang disajikan pada tabel berikut:

Tabel 1. Bobot Nilai Gap

\begin{tabular}{ccl}
\hline Selisih & Bobot Nilai & \multicolumn{1}{c}{ Keterangan } \\
\hline 0 & 5 & Tidak ada selisih (sesuai dengan yang dibutuhkan. \\
1 & 4.5 & Kompetensi individu kelebihan 1 tingkat / level. \\
-1 & 4 & Kompetensi individu kekurangan 1 tingkat / level. \\
2 & 3.5 & Kompetensi individu kelebihan 2 tingkat / level. \\
-2 & 3 & Kompetensi individu kekurangan 2 tingkat / level. \\
3 & 2.5 & Kompetensi individu kelebihan 3 tingkat / level. \\
-3 & 2 & Kompetensi individu kekurangan 3 tingkat / level. \\
4 & 1.5 & Kompetensi individu kelebihan 4 tingkat / level. \\
-4 & 1 & Kompetensi individu kekurangan 4 tingkat / level. \\
\hline
\end{tabular}

d) Perhitungan dan Pengelompokan Core Factor dan Secondary Factor

Setelah menentukan bobot nilai gap untuk semua aspek dengan cara yang sama, setiap aspek dibagi lagi menjadi dua kelompok yaitu kelompok core factor (faktor utama) dan secondary factor (faktor pendukung). Perhitungan core factor dan secondary factor dapat ditunjukkan pada persamaan:

1) Perhitungan Core Factor

$$
N C F=\frac{\sum N C}{\sum I C}
$$

Keterangan

$\mathrm{NCF}$ : Nilai rata-rata core factor

NC : Jumlah total nilai core factor

IC : Jumlah item core factor

2) Perhitungan Secondary Factor

$$
N S F=\frac{\sum N S}{\sum I S}
$$

Keterangan

NSF : Nilai rata-rata secondary factor

NS : Jumlah total nilai secondary factor 
JURNAL MEDIA INFORMATIKA BUDIDARMA

Volume 5, Nomor 1, Januari 2021, Page 108-123

ISSN 2614-5278 (media cetak), ISSN 2548-8368 (media online)

Available Online at https://ejurnal.stmik-budidarma.ac.id/index.php/mib

DOI 10.30865/mib.v5i1.2274

IS : Jumlah item secondary factor

3) Penentuan Presentase Core Factor dan Secondary Factor

Presentase untuk menentukan Core Factor dan Secondary Factor ditentukan berdasarkan organisasi.

Biasanya presentase yang digunakan untuk menghitung nilai Core Factor lebih besar dari pada presentase yang digunakan untuk menghitung Secondary Factor. Hal ini disebabkan karena Core Factor adalah faktor yang lebih utama dibandingkan dengan Secondary Factor.Pada umumnya presentase yang dipakai adalah 60 : 40, sehingga dalam kasus ini nilai presentase yang digunakan untuk Core Factor adalah $60 \%$ dan untuk Secondary Factor $40 \%$.

e) Perhitungan Nilai Total

Dari perhitungan setiap aspek di atas, berikutnya dihitung nilai total berdasarkan persentase dari core factor dan secondary factor yang diperkirakan berpengaruh terhadap kinerja tiap-tiap profil. Contoh perhitungan dapat dilihat dibawah ini:

$$
\mathrm{N}=(\mathrm{x}) \% . \mathrm{NCF}+(\mathrm{x}) \% . \mathrm{NSF}
$$

Keterangan :

NCF : Nilai rata-rata core

NSF : Nilai rata-rata secondary factor

$\mathrm{N} \quad$ : Nilai total dari aspek

$(\mathrm{X}) \% \quad$ : Nilai persentase pada core factor dan secondary factor

f) Perhitungan Penentuan Ranking

Hasil akhir dari proses profile matching adalah ranking dari jurusan yang terbaik untuk calon peserta didik baru. Penentuan ranking mengacu pada hasil perhitungan tertentu. Contoh perhitungan dapat dilihat pada contoh dibawah ini:

\section{$\underline{\text { Rangking }=(\mathrm{x}) \% \cdot \mathrm{nk}+(\mathrm{x}) \% \cdot \mathrm{na}+(\mathrm{x}) . \mathrm{ni}}$}

Keterangan :

$\begin{array}{ll}\mathrm{Nk} & : \text { Nilai Kompetensi } \\ \mathrm{Na} & : \text { Nilai UN } \\ \mathrm{Ni} & : \text { Nilai Minat } \\ \mathrm{X}) \% & : \text { Nilai persen yang diinputkan }\end{array}$

\subsection{Konfigurasi Komponen Sistem Penunjang Keputusan}

Sistem penunjang keputusan untuk menentukan jurusan calon siswa ini memiliki 4 (empat) komponen utama, yaitu : sistem manajemen basis data, sistem manajemen basis model, sistem manajemen dialog (user interface) dan sistam manajemen basis pengetahuan [9]. Selengkapnya dapat dilihat pada gambar 1.

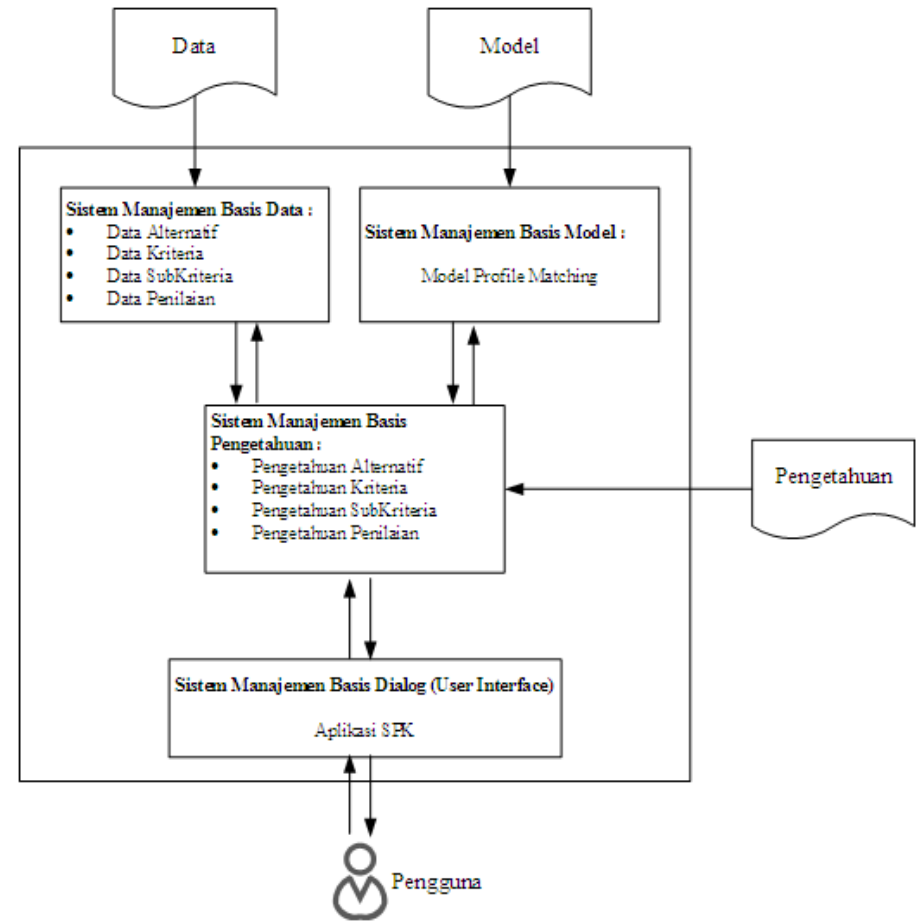

Gambar 1. Konfigurasi Komponen Utama Sistem Penunjang Keputusan 
JURNAL MEDIA INFORMATIKA BUDIDARMA

Volume 5, Nomor 1, Januari 2021, Page 108-123

ISSN 2614-5278 (media cetak), ISSN 2548-8368 (media online)

Available Online at https://ejurnal.stmik-budidarma.ac.id/index.php/mib DOI 10.30865/mib.v5i1.2274

\subsection{Tahapan Penelitian}

Selengkapnya langkah-langkah penelitian tersebut dapa dilihat pada gambar 2 .

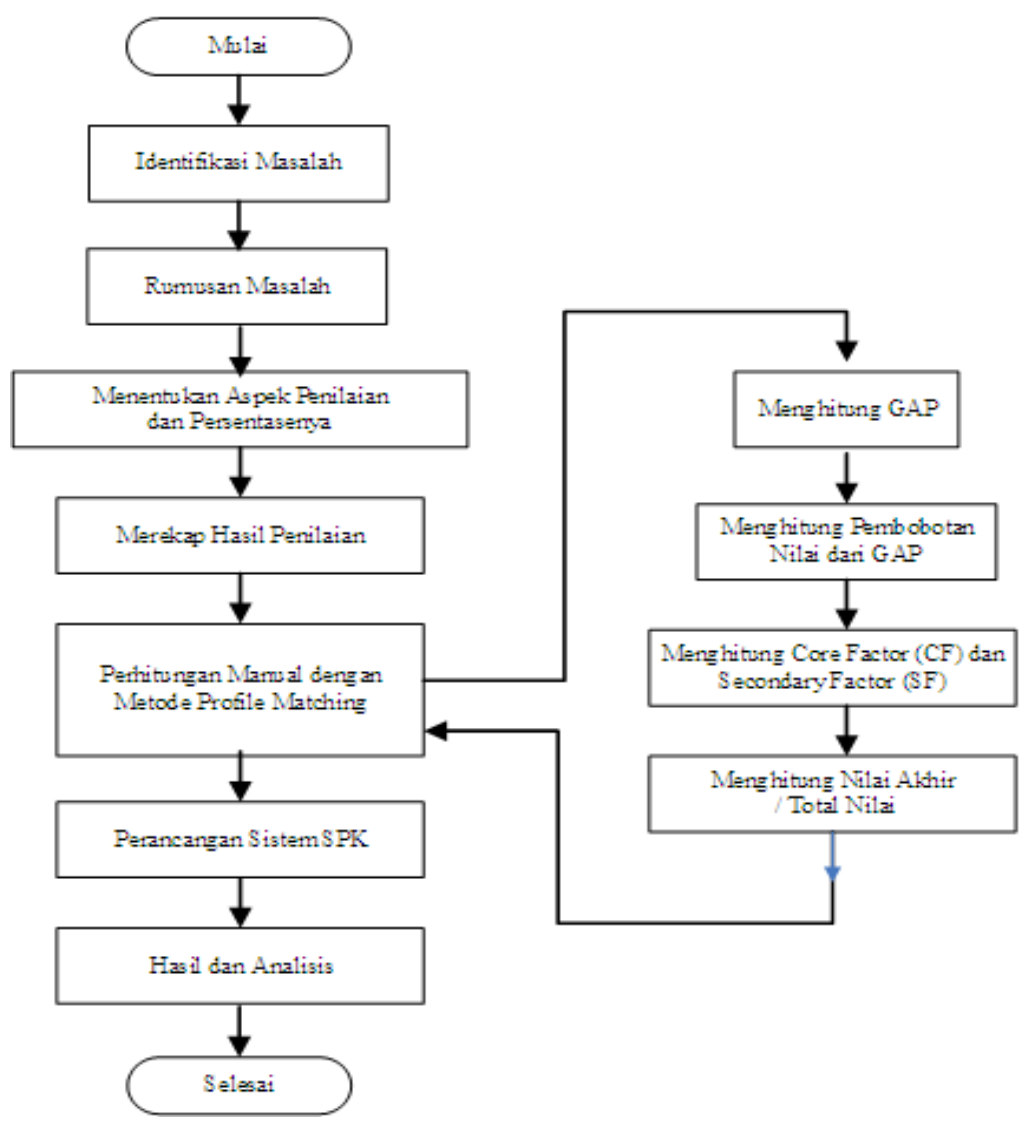

Gambar 2. Langkah-langkah Penelitian

Adapun langkah-langkah yang dilakukan dalam penelitian ini dijelaskan sebagai berikut :

Tahap 1 : Penelitian ini diawali dengan melakukan identifikasi masalah yang terjadi pada SMK XYZ dengan menggunakan pendekatan Fishbone Diagram.

Tahap 2 : Mengidentifikasi solusi masalah dan merumuskan masalah berdasarkan hasil kajian teori dan studi literature.

Tahap 3 : Menentukan aspek penilaian dan persentase setiap kriteria penilaian.

Tahap 4 : Merekap hasil penilaian menggunakan aplikasi Ms. Excel.

Tahap 5 : Melakukan perhitungan manual menggunakan metode Profile Matching.

Tahap 6 : Melakukan analisa dan perancangan sistem usulan. Pendekatan yang digunakan untuk menganalisa sistem pada penelitian ini menggunakan Object-Oriented Analysis and Design (OOAD). Pendekatan tersebut merupakan salah satu teknik dalam pengembangan sistem menggunakan teknologi object untuk membangun sistem dan perangkat lunaknya [10]. Alat bantu yang digunakan adalah Unified Modeling Language (UML), yaitu bahasa yang terstandarisasi secara internasional untuk notasi berbentuk diagram grafik yang menjelaskan tentang analisis dan ].perancangan perangkat lunak dengan pendekatan Object-Oriented [11]. Diagram UML yang digunakan dalam penelitian ini antara lain: Activity Diagram dan Use Case Diagram, dan untuk implementasi sistem usulan dengan menggunakan bahasa pemrograman dan database management system (DBMS).

Tahap 7 : Penentuan hasil dan melakukan analisis hasil penelitian.

\section{HASIL DAN PEMBAHASAN}

\subsection{Analisa Proses Bisnis}

Saat awal tahun ajaran baru bagian kesiswaan akan mengadakan tes potensi akademik yang akan dikerjakan oleh calon siswa peserta didik baru sebagai acuan penentuan penjurusan. Setelah tes potensi akademik selesai, siswa calon peserta didik baru akan diberikan form peminatan untuk memperoleh informasi jurusan yang ingin dipilih. Lalu bagian kesiswaan akan menilai hasil tes potensi akademik calon peserta didik baru dan melakukan penjurusan berdasarkan hasil pengisian form peminatan. Hasil penjurusan dari bagian kesiswaan ini lalu 
JURNAL MEDIA INFORMATIKA BUDIDARMA

Volume 5, Nomor 1, Januari 2021, Page 108-123

ISSN 2614-5278 (media cetak), ISSN 2548-8368 (media online)

Available Online at https://ejurnal.stmik-budidarma.ac.id/index.php/mib

DOI 10.30865/mib.v5i1.2274

diberikan kepada bagian kurikulum untuk dirapatkan dengan kepala sekolah. Setelah hasil rapat selesai penentuan penjurusan siswa peserta didik baru akan diumumkan melalui mading sekolah oleh bagian kurikulum. Proses bisnis berjalan saat ini tertera pada gambar 3 .

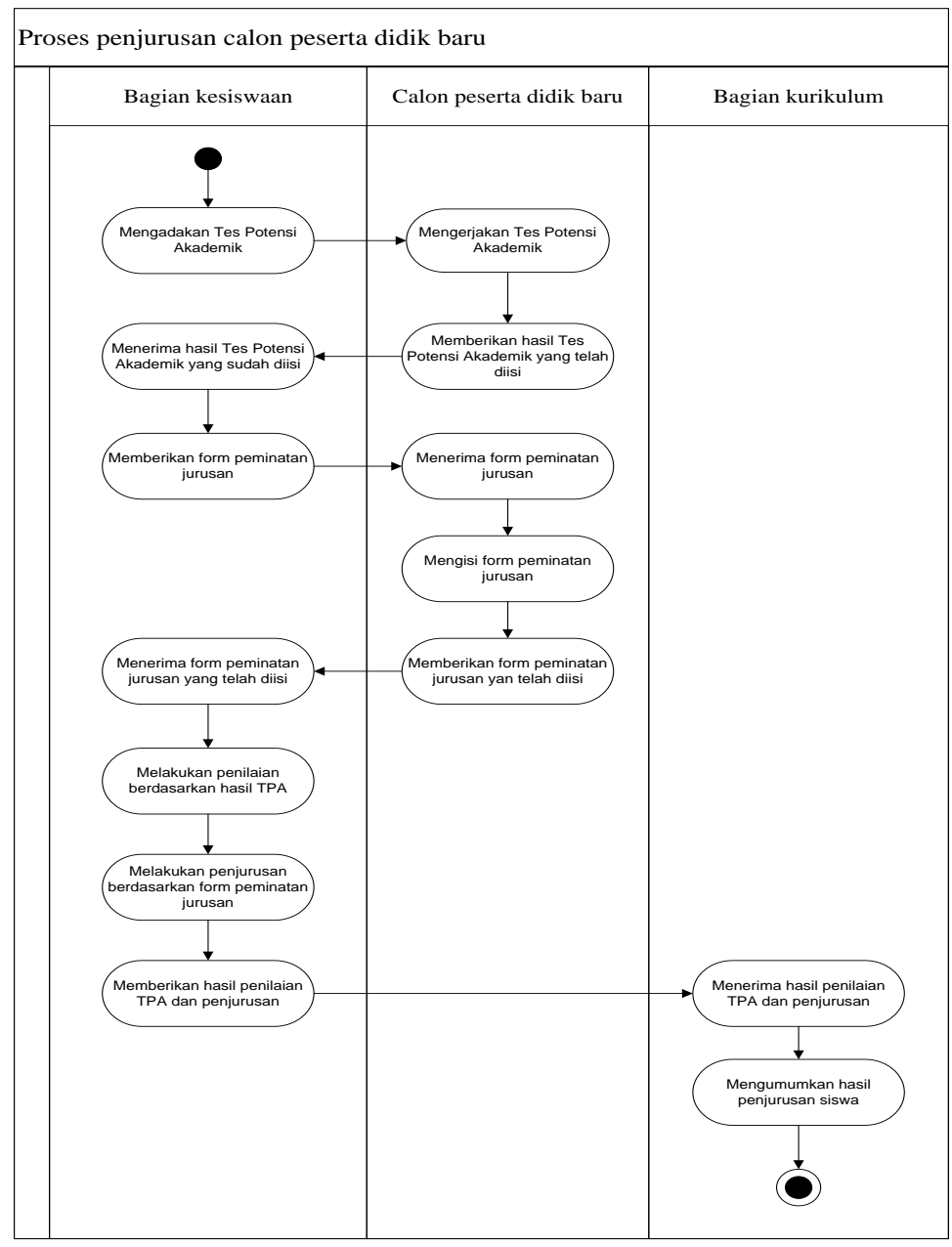

Gambar 3. Activity Diagram Penjurusan Calon Siswa

\subsection{Analisa Masalah}

Dalam penelitian ini, penulis menggunakan alat bantu Fishbone Diagram untuk melakukan identifikasi masalah yang terjadi di intansi riset. Fishbone Diagram adalah tools yang digunakan untuk menggambarkan dampak / akibat dan penyebab dari suatu kejadian [12]. Masalah utama pada penelitian yang dilakukan di SMK XYZ adalah ketidakcocokan antara profil calon siswa terhadap jurusan yang pilih, pengambilan keputusan calon siswa kurang tepat karena hanya berdasarkan persepsi staf kesiswaan, membutuhkan waktu yang lama untuk mengolah data penilaian calon siswa dan belum ada kriteria khusus dan pembobotan nilai untuk menentukan jurusan calon siswa. Adapun hasil analisa masalah terkait penjurusan calon peserta didik baru dapat dilihat pada gambar 4 .

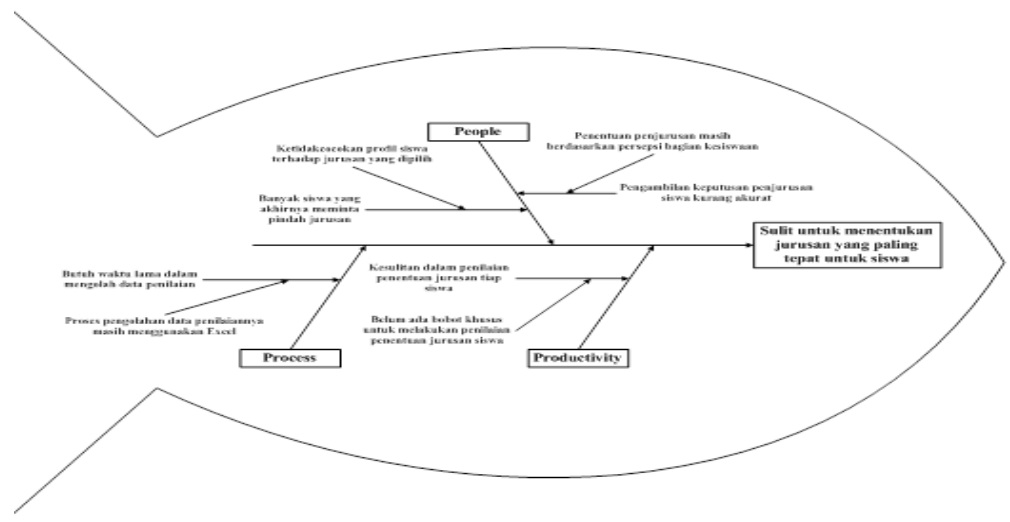

Gambar 4. Analisa Masalah dengan Fishbone Diagram 
JURNAL MEDIA INFORMATIKA BUDIDARMA

Volume 5, Nomor 1, Januari 2021, Page 108-123

ISSN 2614-5278 (media cetak), ISSN 2548-8368 (media online)

Available Online at https://ejurnal.stmik-budidarma.ac.id/index.php/mib

DOI 10.30865/mib.v5i1.2274

Berdasarkan hasil analisa masalah diatas, maka peneliti menawarkan solusi alternatif untuk sistem usulan dijelaskan pada tabel 1 .

Tabel 1. Definisi Masalah Dan Solusi Alternatif

\begin{tabular}{|c|c|c|c|}
\hline $\begin{array}{l}\text { Kategori } \\
\text { Masalah }\end{array}$ & Definisi Masalah & Penyebab & Solusi yang ditawarkan \\
\hline $\begin{array}{l}\text { Process } \\
\text { (Proses) }\end{array}$ & $\begin{array}{l}\text { - Kesulitan dalam } \\
\text { menentukan jurusan calon } \\
\text { peserta didik baru }\end{array}$ & $\begin{array}{l}\text { - Penentuan jurusan } \\
\text { berdasarkan persepsi } \\
\text { bagian kesiswaaan }\end{array}$ & $\begin{array}{l}\text { - Sistem baru harus bisa menentukan } \\
\text { jurusan peserta didik baru } \\
\text { berdasarkan kriteria yang ada. }\end{array}$ \\
\hline $\begin{array}{l}\text { Process } \\
\text { (Proses) }\end{array}$ & $\begin{array}{l}\text { - Banyak siswa yang meminta } \\
\text { pindah jurusan. }\end{array}$ & $\begin{array}{l}\text { - Ketidakcocokan profil } \\
\text { siswa terhadap jurusan } \\
\text { yang dipilih. }\end{array}$ & $\begin{array}{l}\text { - Sistem baru harus bisa memastikan } \\
\text { kecocokan profil siswa dengan } \\
\text { jurusan yang dipilih. }\end{array}$ \\
\hline $\begin{array}{l}\text { Process } \\
\text { (Proses) }\end{array}$ & $\begin{array}{l}\text { - Pengolahan data penentuan } \\
\text { jurusan calon peserta didik } \\
\text { baru membutuhkan waktu } \\
\text { yang lama }\end{array}$ & $\begin{array}{l}\text { - Masih dilakukan } \\
\text { menggunakan aplikasi } \\
\text { Excel. }\end{array}$ & $\begin{array}{l}\text { - Sistem baru harus bisa mengolah } \\
\text { data penentuan jurusan calon } \\
\text { peserta didik baru dengan cepat. }\end{array}$ \\
\hline $\begin{array}{l}\text { Promotion } \\
\text { (Promosi) }\end{array}$ & $\begin{array}{l}\text { - Kesulitan dalam penilaian } \\
\text { penentuan jurusan tiap calon } \\
\text { peserta didik baru. }\end{array}$ & $\begin{array}{l}\text { - Belum ada kriteria } \\
\text { untuk menentukan } \\
\text { penjurusan calon } \\
\text { peserta didik baru. }\end{array}$ & $\begin{array}{l}\text { - Sistem usulan harus bisa merekam } \\
\text { kriteria untuk menentukan } \\
\text { penjurusan calon peserta didik baru. }\end{array}$ \\
\hline
\end{tabular}

\subsection{Model Keputusan Profile Matching}

Metode Profile Matching digunakan untuk melakukan perhitungan penjurusan yang paling cocok untuk peserta didik baru.

a. Nilai Target

Tabel 2,3,4 merupakan nilai target per kriteria dan subkriteria dari masing-masing jurusan yang sudah ditentukan oleh pihak sekolah.

Tabel 2. Nilai Target Jurusan MM

\begin{tabular}{ccccc}
\hline No. & Kriteria & Subkriteria & Nilai & Factor \\
& & & Target & \\
\hline 1. & Tes Potensi Akademik & Pengetahuan & 3 & Core \\
2. & Nilai Ujian Nasional & IPA & 2 & Secondary \\
& & Bahasa Indonesia & 4 & Core \\
& & Bahasa Inggris & 4 & Core \\
& & Matematika & 3 & Secondary \\
3. & Angket Minat & Minat Siswa & 3 & Core \\
\hline
\end{tabular}

Tabel 3. Nilai Target Nilai Target Jurusan TKJ

\begin{tabular}{ccccc}
\hline No. & Kriteria & Subkriteria & $\begin{array}{c}\text { Nilai } \\
\text { Target }\end{array}$ & Factor \\
\hline 1. & Tes Potensi Akademik & Pengetahuan & 4 & Core \\
2. & Nilai Ujian Nasional & IPA & 2 & Secondary \\
& & Bahasa Indonesia & 3 & Secondary \\
& & Bahasa Inggris & 4 & Core \\
& & Matematika & 4 & Core \\
3. & Angket Minat & Minat Siswa & 4 & Core \\
\hline
\end{tabular}

Tabel 4. Nilai Target Jurusan RPL

\begin{tabular}{ccccc}
\hline No. & Kriteria & Subkriteria & $\begin{array}{c}\text { Nilai } \\
\text { Target }\end{array}$ & Factor \\
\hline 1. & Tes Potensi Akademik & Pengetahuan & 5 & Core \\
2. & Nilai Ujian Nasional & IPA & 2 & Secondary \\
& & Bahasa Indonesia & 4 & Secondary \\
& & Bahasa Inggris & 4 & Core \\
& & Matematika & 5 & Core \\
3. & Angket Minat & Minat Siswa & 5 & Core \\
\hline
\end{tabular}

\section{b. Range Nilai}

Setelah menentukan nilai target per kriteria untuk masing-masing jurusan, lalu menentukan range nilai yang akan digunakan dalam proses konversi nilai awal menjadi nilai target seperti pada tabel 5 . 
ISSN 2614-5278 (media cetak), ISSN 2548-8368 (media online)

Available Online at https://ejurnal.stmik-budidarma.ac.id/index.php/mib DOI 10.30865/mib.v5i1.2274

Tabel 5. Range Nilai

\begin{tabular}{cc}
\hline & Data Range Nilai \\
\hline 1 & Nilai $>=0 \mathrm{~s} / \mathrm{d}<=20$ \\
2 & Nilai $>=21 \mathrm{~s} / \mathrm{d}<=40$ \\
3 & Nilai $>=41 \mathrm{~s} / \mathrm{d}<=60$ \\
4 & Nilai $>=61 \mathrm{~s} / \mathrm{d}<=80$ \\
5 & Nilai $>=81 \mathrm{~s} / \mathrm{d}<=100$ \\
\hline
\end{tabular}

\section{c. Perhitungan Hasil Konversi Nilai Awal}

Nilai awal calon peserta didik naru yang sudah dimasukkan ke sistem selanjutnya akan dikonversikan menjadi nilai target kriteria yang sudah ditentukan di awal. Berikut adalah contoh hasil konversi nilai awal untuk setiap jurusan seperti pada tabel 6,7,8.

Tabel 7. Hasil Konversi Nilai MM

\begin{tabular}{llllllll}
\hline No. & NIS & $\begin{array}{l}\text { Tes Potensi } \\
\text { Akademik } \\
\text { Pengetahuan }\end{array}$ & IPA & $\begin{array}{l}\text { Nilai Ujian Nasional } \\
\text { Bahasa } \\
\text { Indonesia }\end{array}$ & $\begin{array}{l}\text { Bahasa } \\
\text { Inggris }\end{array}$ & Matematika & $\begin{array}{l}\text { Angket } \\
\text { Minat } \\
\text { Minat } \\
\text { Siswa }\end{array}$ \\
\hline 1. & S001 & 4 & 3 & 4 & 3 & 3 & 5 \\
2. & S002 & 2 & 3 & 4 & 4 & 3 & 5 \\
3. & S003 & 5 & 4 & 3 & 1 & 2 & 4 \\
4. & S004 & 4 & 2 & 5 & 3 & 5 & 3 \\
5. & S005 & 3 & 3 & 4 & 2 & 4 & 2 \\
6. & S006 & 3 & 4 & 5 & 4 & 3 & 5 \\
\hline
\end{tabular}

Tabel 8. Hasil Konversi Nilai TKJ

\begin{tabular}{|c|c|c|c|c|c|c|c|}
\hline \multirow[t]{2}{*}{ No. } & \multirow[t]{2}{*}{ NIS } & \multirow{2}{*}{$\begin{array}{l}\text { Tes Potensi } \\
\text { Akademik } \\
\text { Pengetahuan }\end{array}$} & \multicolumn{4}{|c|}{ Nilai Ujian Nasional } & \multirow{2}{*}{$\begin{array}{l}\text { Angket } \\
\text { Minat } \\
\text { Minat } \\
\text { Siswa }\end{array}$} \\
\hline & & & IPA & $\begin{array}{l}\text { Bahasa } \\
\text { Indonesia }\end{array}$ & $\begin{array}{l}\text { Bahasa } \\
\text { Inggris }\end{array}$ & Matematika & \\
\hline 1. & S001 & 4 & 3 & 4 & 3 & 3 & 5 \\
\hline 2. & S002 & 2 & 3 & 4 & 4 & 3 & 5 \\
\hline 5. & S005 & 3 & 3 & 4 & 2 & 4 & 2 \\
\hline 6. & S006 & 3 & 4 & 5 & 4 & 3 & 5 \\
\hline
\end{tabular}

Tabel 9. Hasil Konversi Nilai RPL

\begin{tabular}{llllllll}
\hline No. & NIS & $\begin{array}{l}\text { Tes Potensi } \\
\text { Akademik } \\
\text { Pengetahuan }\end{array}$ & IPA & $\begin{array}{l}\text { Nilai Ujian Nasional } \\
\text { Bahasa } \\
\text { Indonesia }\end{array}$ & $\begin{array}{l}\text { Bahasa } \\
\text { Inggris }\end{array}$ & Matematika & $\begin{array}{l}\text { Angket } \\
\text { Minat } \\
\text { Minat } \\
\text { Siswa }\end{array}$ \\
\hline 1. & S001 & 4 & 3 & 4 & 3 & 3 & 5 \\
2. & S002 & 2 & 3 & 4 & 4 & 3 & 5 \\
3. & S003 & 5 & 4 & 3 & 1 & 2 & 4 \\
4. & S004 & 4 & 2 & 5 & 3 & 5 & 3 \\
5. & S005 & 3 & 3 & 4 & 2 & 4 & 2 \\
6. & S006 & 3 & 4 & 5 & 4 & 3 & 5 \\
\hline
\end{tabular}

d. Perhitungan Pemetaan GAP Kompetensi

Berikutnya adalah melakukan penghitungan gap kompetensi yaitu selisih antara nilai target per kriteria masingmasing jurusan dan nilai hasil konversi dari masing-masing calon peserta didik baru seperti pada tabel 10,11,12.

Tabel 10. Pemetaan Gap Jurusan MM

\begin{tabular}{cccccccc}
\hline & \multicolumn{4}{c}{ GAP (Nilai Per Kriteria - Nilai Target) } & & \\
& NIS & Pengetahuan & IPA & $\begin{array}{c}\text { Bahasa } \\
\text { Indonesia }\end{array}$ & $\begin{array}{c}\text { Bahasa } \\
\text { Inggris }\end{array}$ & Matematika & $\begin{array}{c}\text { Minat } \\
\text { Siswa }\end{array}$ \\
\hline 1. & S001 & 1 & 1 & 0 & -1 & 0 & 2 \\
2. & S002 & -1 & 1 & 0 & 0 & 0 & 2 \\
3. & S003 & 2 & 2 & -1 & -3 & -1 & 1 \\
\hline
\end{tabular}


JURNAL MEDIA INFORMATIKA BUDIDARMA

Volume 5, Nomor 1, Januari 2021, Page 108-123

ISSN 2614-5278 (media cetak), ISSN 2548-8368 (media online)

Available Online at https://ejurnal.stmik-budidarma.ac.id/index.php/mib

DOI 10.30865/mib.v5i1.2274

\begin{tabular}{cccccccc}
\hline 4. & S004 & 1 & 0 & 1 & -1 & 2 & 0 \\
5. & S005 & 0 & 1 & 0 & -2 & 1 & -1 \\
6. & S006 & 0 & 2 & 1 & 0 & 0 & 2 \\
\hline
\end{tabular}

Tabel 11. Pemetaan Gap Jurusan TKJ

\begin{tabular}{|c|c|c|c|c|c|c|c|}
\hline \multicolumn{8}{|c|}{ GAP (Nilai Per Kriteria - Nilai Target) } \\
\hline & NIS & Pengetahuan & IPA & Bahasa & Bahasa & Matematika & Minat \\
\hline & & & & Indonesia & Inggris & & Siswa \\
\hline 1. & S001 & 0 & 1 & 1 & -1 & -1 & 1 \\
\hline 2. & S002 & -2 & 1 & 1 & 0 & -1 & 1 \\
\hline 3. & S003 & 1 & 2 & 0 & -3 & -2 & 0 \\
\hline 4. & S004 & 0 & 0 & 2 & -1 & 1 & -1 \\
\hline 5. & S005 & -1 & 1 & 1 & -2 & 0 & -2 \\
\hline 6. & S006 & -1 & 2 & 2 & 0 & -1 & 1 \\
\hline
\end{tabular}

Tabel 12. Pemetaan Gap Jurusan RPL

\begin{tabular}{|c|c|c|c|c|c|c|c|}
\hline \multicolumn{8}{|c|}{ GAP (Nilai Per Kriteria - Nilai Target) } \\
\hline & NIS & Pengetahuan & IPA & $\begin{array}{l}\text { Bahasa } \\
\text { Indonesia }\end{array}$ & $\begin{array}{l}\text { Bahasa } \\
\text { Inggris }\end{array}$ & Matematika & $\begin{array}{l}\text { Minat } \\
\text { Siswa }\end{array}$ \\
\hline 1. & S001 & -1 & 1 & 0 & -1 & -2 & 0 \\
\hline 2. & S002 & -3 & 1 & 0 & 0 & -2 & 0 \\
\hline 3. & S003 & 0 & 2 & -1 & -3 & -3 & -1 \\
\hline 4. & S004 & -1 & 0 & 1 & -1 & 0 & -2 \\
\hline 5. & S005 & -2 & 1 & 0 & -2 & -1 & -3 \\
\hline 6. & S006 & -2 & 2 & 1 & 0 & -2 & 0 \\
\hline
\end{tabular}

\section{e. Pembobotan}

Setelah diperoleh Gap pada masing-masing jurusan, setiap jurusan diberi bobot sesuai ketentuan pada tabel 10 , 11 dan 12. Dan hasil dari konversi gap menjadi bobot ada pada tabel 13,14,15 dan 16 .

Tabel 13. Bobot Profile Matching

\begin{tabular}{ccl}
\hline Selisih & Bobot Nilai & \multicolumn{1}{c}{ Keterangan } \\
\hline 0 & 5 & Tidak ada selisih (sesuai dengan yang dibutuhkan. \\
1 & 4.5 & Kompetensi individu kelebihan 1 tingkat \\
-1 & 4 & Kompetensi individu kekurangan 1 tingkat \\
2 & 3.5 & Kompetensi individu kelebihan 2 tingkat \\
-2 & 3 & Kompetensi individu kekurangan 2 tingkat \\
3 & 2.5 & Kompetensi individu kelebihan 3 tingkat \\
-3 & 2 & Kompetensi individu kekurangan 3 tingkat \\
4 & 1.5 & Kompetensi individu kelebihan 4 tingkat \\
-4 & 1 & Kompetensi individu kekurangan 4 tingkat \\
\hline
\end{tabular}

Tabel 14. Pembobotan Nilai Jurusan MM

\begin{tabular}{|c|c|c|c|c|c|c|c|}
\hline \multicolumn{8}{|c|}{ GAP (Nilai Per Kriteria - Nilai Target) } \\
\hline & NIS & Pengetahuan & IPA & $\begin{array}{l}\text { Bahasa } \\
\text { Indonesia }\end{array}$ & $\begin{array}{l}\text { Bahasa } \\
\text { Inggris }\end{array}$ & Matematika & $\begin{array}{l}\text { Minat } \\
\text { Siswa }\end{array}$ \\
\hline 1. & S001 & -1 & 1 & 0 & -1 & -2 & 0 \\
\hline 2. & S002 & -3 & 1 & 0 & 0 & -2 & 0 \\
\hline 3. & S003 & 0 & 2 & -1 & -3 & -3 & -1 \\
\hline 4. & S004 & -1 & 0 & 1 & -1 & 0 & -2 \\
\hline 5. & S005 & -2 & 1 & 0 & -2 & -1 & -3 \\
\hline 6. & S006 & -2 & 2 & 1 & 0 & -2 & 0 \\
\hline
\end{tabular}

Tabel 15. Pembobotan Nilai Jurusan TKJ

\begin{tabular}{cccccccc}
\hline & \multicolumn{4}{c}{ GAP (Nilai Per Kriteria - Nilai Target) } & & \\
& NIS & Pengetahuan & IPA & Bahasa & Bahasa & Matematika & $\begin{array}{c}\text { Minat } \\
\text { Siswa }\end{array}$ \\
\hline 1. & S001 & 4.5 & 4.5 & 5.0 & 4.0 & 5.0 & 3.5 \\
2. & S002 & 4.0 & 4.5 & 5.0 & 5.0 & 5.0 & 3.5 \\
3. & S003 & 3.5 & 3.5 & 4.0 & 2.0 & 4.0 & 4.5 \\
\hline
\end{tabular}


JURNAL MEDIA INFORMATIKA BUDIDARMA

Volume 5, Nomor 1, Januari 2021, Page 108-123

ISSN 2614-5278 (media cetak), ISSN 2548-8368 (media online)

Available Online at https://ejurnal.stmik-budidarma.ac.id/index.php/mib

DOI 10.30865/mib.v5i1.2274

\begin{tabular}{llllllll}
4. & $\mathrm{~S} 004$ & 4.5 & 5.0 & 4.5 & 4.0 & 3.5 & 5.0 \\
5. & $\mathrm{~S} 005$ & 5.0 & 4.5 & 5.0 & 3.0 & 4.5 & 4.0 \\
6. & $\mathrm{~S} 006$ & 5.0 & 3.5 & 4.5 & 5.0 & 5.0 & 3.5 \\
\hline
\end{tabular}

Tabel 16. Pembobotan Nilai Jurusan RPL

GAP (Nilai Per Kriteria - Nilai Target)

\begin{tabular}{cccccccc} 
& NIS & Pengetahuan & IPA & $\begin{array}{c}\text { Bahasa } \\
\text { Indonesia }\end{array}$ & $\begin{array}{c}\text { Bahasa } \\
\text { Inggris }\end{array}$ & Matematika & $\begin{array}{c}\text { Minat } \\
\text { Siswa }\end{array}$ \\
\hline 1. & S001 & 4.0 & 4.5 & 5.0 & 4.0 & 3.0 & 5.0 \\
2. & S002 & 2.0 & 4.5 & 5.0 & 5.0 & 3.0 & 5.0 \\
3. & S003 & 5.0 & 3.5 & 4.0 & 2.0 & 2.0 & 4.0 \\
4. & S004 & 4.0 & 5.0 & 4.5 & 4.0 & 5.0 & 3.0 \\
5. & S005 & 3.0 & 4.5 & 5.0 & 3.0 & 4.0 & 2.0 \\
6. & S006 & 3.0 & 3.5 & 4.5 & 5.0 & 3.0 & 5.0 \\
\hline
\end{tabular}

\section{f. Perhitungan dan pengelompokan Core Factor dan Secondary Factor}

Setelah bobot nilai gap ditentukan untuk tiap subkriteria maka kemudian subkriteria dibagi menjadi 2 (dua) bagian yaitu core factor dan secondary factor. Berikut merupakan salah satu perhitungan untuk core factor dan secondary factor per masing-masing jurusan dapat dilihat pada tabel 17, 18, 19 .

Tabel 17. Perhitungan CF\&SF Jurusan MM

\begin{tabular}{|c|c|c|c|c|c|c|c|c|c|c|c|c|c|}
\hline \multirow[t]{2}{*}{ No. } & \multirow[t]{2}{*}{ NIS } & \multicolumn{3}{|c|}{ Tes Potensi Akademik } & \multicolumn{6}{|c|}{ Nilai Ujian Nasional } & \multicolumn{3}{|c|}{ Angket Minat } \\
\hline & & Pengetahuan & $\begin{array}{c}\text { Total } \\
\text { CF } \\
(60 \%)\end{array}$ & $\begin{array}{c}\text { Total } \\
\text { SF } \\
(40 \%) \\
\end{array}$ & IPA & $\begin{array}{c}\text { Bahasa } \\
\text { Indonesia }\end{array}$ & $\begin{array}{l}\text { Bahasa } \\
\text { Inggris }\end{array}$ & Matematika & $\begin{array}{c}\text { Total } \\
\text { CF } \\
(60 \%)\end{array}$ & $\begin{array}{c}\text { Total } \\
\text { SF } \\
(40 \%)\end{array}$ & $\begin{array}{l}\text { Minat } \\
\text { Siswa }\end{array}$ & $\begin{array}{c}\text { Total } \\
\text { CF } \\
(60 \%)\end{array}$ & $\begin{array}{c}\text { Total } \\
\text { SF } \\
(40 \%)\end{array}$ \\
\hline 1. & S001 & 4.5 & 2.70 & - & 4.5 & 5.0 & 4.0 & 5.0 & 2.70 & 1.90 & 3.5 & - & 1.40 \\
\hline 2. & S002 & 4.0 & 2.40 & - & 4.5 & 5.0 & 5.0 & 5.0 & 3.00 & 1.90 & 3.5 & - & 1.40 \\
\hline 3. & S003 & 3.5 & 2.10 & - & 3.5 & 4.0 & 2.0 & 4.0 & 1.80 & 1.50 & 4.5 & - & 1.80 \\
\hline 4. & S004 & 4.5 & 2.70 & - & 5.0 & 4.5 & 4.0 & 3.5 & 2.55 & 1.70 & 5.0 & - & 2.00 \\
\hline 5. & S005 & 5.0 & 3.00 & - & 4.5 & 5.0 & 3.0 & 4.5 & 2.40 & 1.80 & 4.0 & - & 1.60 \\
\hline 6. & S006 & 5.0 & 3.00 & - & 3.5 & 4.5 & 5.0 & 5.0 & 2.85 & 1.70 & 3.5 & - & 1.40 \\
\hline
\end{tabular}

Tabel 18. Perhitungan CF\&SF Jurusan TKJ

\begin{tabular}{|c|c|c|c|c|c|c|c|c|c|c|c|c|c|}
\hline \multirow[t]{2}{*}{ No. } & \multirow[t]{2}{*}{ NIS } & \multicolumn{3}{|c|}{ Tes Potensi Akademik } & \multicolumn{6}{|c|}{ Nilai Ujian Nasional } & \multicolumn{3}{|c|}{ Angket Minat } \\
\hline & & Pengetahuan & $\begin{array}{c}\text { Total } \\
\text { CF } \\
(60 \%) \\
\end{array}$ & $\begin{array}{c}\text { Total } \\
\text { SF } \\
(40 \%) \\
\end{array}$ & IPA & $\begin{array}{c}\text { Bahasa } \\
\text { Indonesia }\end{array}$ & $\begin{array}{l}\text { Bahasa } \\
\text { Inggris }\end{array}$ & Matematika & $\begin{array}{c}\text { Total } \\
\text { CF } \\
(60 \%) \\
\end{array}$ & $\begin{array}{c}\text { Total } \\
\text { SF } \\
(40 \%) \\
\end{array}$ & $\begin{array}{l}\text { Minat } \\
\text { Siswa }\end{array}$ & $\begin{array}{c}\text { Total } \\
\text { CF } \\
(60 \%) \\
\end{array}$ & $\begin{array}{c}\text { Total } \\
\text { SF } \\
(40 \%) \\
\end{array}$ \\
\hline 1. & S001 & 5.0 & 3.00 & - & 4.5 & 4.5 & 4.0 & 4.0 & 2.50 & 1.80 & 4.5 & - & 1.80 \\
\hline 2. & S002 & 3.0 & 1.80 & - & 4.5 & 4.5 & 5.0 & 4.0 & 2.70 & 1.80 & 4.5 & - & 1.80 \\
\hline 3. & S003 & 4.5 & 2.70 & - & 3.5 & 5.0 & 2.0 & 3.0 & 2.00 & 1.40 & 5.0 & - & 2.00 \\
\hline 4. & S004 & 5.0 & 3.00 & - & 5.0 & 3.5 & 4.0 & 4.5 & 2.40 & 2.00 & 4.0 & - & 1.60 \\
\hline 5. & S005 & 4.0 & 2.40 & - & 4.5 & 4.5 & 3.0 & 5.0 & 2.50 & 1.80 & 3.0 & - & 1.20 \\
\hline 6. & S006 & 4.0 & 2.40 & - & 3.5 & 3.5 & 5.0 & 4.0 & 2.50 & 1.40 & 4.5 & - & 1.80 \\
\hline
\end{tabular}

Tabel 19. Perhitungan CF\&SF Jurusan RPL

\begin{tabular}{|c|c|c|c|c|c|c|c|c|c|c|c|c|c|}
\hline \multirow[t]{2}{*}{ No. } & \multirow[t]{2}{*}{ NIS } & \multicolumn{3}{|c|}{ Tes Potensi Akademik } & \multicolumn{6}{|c|}{ Nilai Ujian Nasional } & \multicolumn{3}{|c|}{ Angket Minat } \\
\hline & & Pengetahuan & $\begin{array}{c}\text { Total } \\
\mathrm{CF} \\
(60 \%)\end{array}$ & $\begin{array}{c}\text { Total } \\
\text { SF } \\
(40 \%) \\
\end{array}$ & IPA & $\begin{array}{c}\text { Bahasa } \\
\text { Indonesia }\end{array}$ & $\begin{array}{l}\text { Bahasa } \\
\text { Inggris }\end{array}$ & Matematika & $\begin{array}{c}\text { Total } \\
\text { CF } \\
(60 \%)\end{array}$ & $\begin{array}{c}\text { Total } \\
\text { SF } \\
(40 \%)\end{array}$ & $\begin{array}{l}\text { Minat } \\
\text { Siswa }\end{array}$ & $\begin{array}{c}\text { Total } \\
\text { CF } \\
(60 \%)\end{array}$ & $\begin{array}{c}\text { Total } \\
\text { SF } \\
(40 \%)\end{array}$ \\
\hline 1. & S001 & 4.0 & 2.40 & - & 4.5 & 5.0 & 4.0 & 3.0 & 2.40 & 1.80 & 5.0 & - & 2.00 \\
\hline 2. & S002 & 2.0 & 1.20 & - & 4.5 & 5.0 & 5.0 & 3.0 & 2.60 & 1.80 & 5.0 & - & 2.00 \\
\hline 3. & S003 & 5.0 & 3.00 & - & 3.5 & 4.0 & 2.0 & 2.0 & 1.60 & 1.40 & 4.0 & - & 1.60 \\
\hline 4. & S004 & 4.0 & 2.40 & - & 5.0 & 4.5 & 4.0 & 5.0 & 2.70 & 2.00 & 3.0 & - & 1.20 \\
\hline 5. & S005 & 3.0 & 1.80 & - & 4.5 & 5.0 & 3.0 & 4.0 & 2.40 & 1.80 & 2.0 & - & 0.80 \\
\hline 6. & S006 & 3.0 & 1.80 & - & 3.5 & 4.5 & 5.0 & 3.0 & 2.50 & 1.40 & 5.0 & - & 2.00 \\
\hline
\end{tabular}

g. Perhitungan Penentuan Hasil Akhir

Setelah dilakukan perhitungan core factor dan secondary factor, maka dilakukan penjumlahan nilai-nilai per kriteria masing-masing jurusan yang hasil akhirnya nanti akan digunakan untuk penentuan jurusan calon peserta didik baru. Berikut ini contoh hasil perhitungan nilai akhir yang terdapat pada tabel 20,21,22.

Tabel 20. Hasil Akhir Nilai Jurusan MM

\begin{tabular}{lccccc}
\hline No. & NIS & $\begin{array}{c}\text { Tes Potensi } \\
\text { Akademik }\end{array}$ & $\begin{array}{c}\text { Nilai Ujian } \\
\text { Nasional }\end{array}$ & Angket Minat & Nilai Akhir \\
\hline 1. & S001 & 2.70 & 4.60 & 1.40 & 8.70 \\
2. & S002 & 2.40 & 4.90 & 1.40 & 8.70 \\
\hline
\end{tabular}


JURNAL MEDIA INFORMATIKA BUDIDARMA

Volume 5, Nomor 1, Januari 2021, Page 108-123

ISSN 2614-5278 (media cetak), ISSN 2548-8368 (media online)

Available Online at https://ejurnal.stmik-budidarma.ac.id/index.php/mib DOI 10.30865/mib.v5i1.2274

\begin{tabular}{llllll}
\hline 3. & S003 & 2.10 & 3.30 & 1.80 & 7.20 \\
4. & S004 & 2.70 & 4.25 & 2.00 & 8.95 \\
5. & S005 & 3.00 & 4.20 & 1.60 & 8.80 \\
6. & S006 & 3.00 & 4.55 & 1.40 & 8.95 \\
\hline
\end{tabular}

Tabel 21. Hasil Akhir Nilai Jurusan TKJ

\begin{tabular}{lccccc}
\hline No. & NIS & $\begin{array}{c}\text { Tes Potensi } \\
\text { Akademik }\end{array}$ & $\begin{array}{c}\text { Nilai Ujian } \\
\text { Nasional }\end{array}$ & Angket Minat & Nilai Akhir \\
\hline 1. & S001 & 3.00 & 4.30 & 1.80 & 9.10 \\
2. & S002 & 1.80 & 4.50 & 1.80 & 8.10 \\
3. & S003 & 2.70 & 3.40 & 2.00 & 8.10 \\
4. & S004 & 3.00 & 4.40 & 1.60 & 9.00 \\
5. & S005 & 2.40 & 4.30 & 1.20 & 7.90 \\
6. & S006 & 2.40 & 3.90 & 1.80 & 8.10 \\
\hline
\end{tabular}

Tabel 22. Hasil Akhir Nilai Jurusan RPL

\begin{tabular}{llcccc}
\hline No. & NIS & $\begin{array}{c}\text { Tes Potensi } \\
\text { Akademik }\end{array}$ & $\begin{array}{c}\text { Nilai Ujian } \\
\text { Nasional }\end{array}$ & Angket Minat & Nilai Akhir \\
\hline 1. & S001 & 2.40 & 4.20 & 2.00 & 8.60 \\
2. & S002 & 1.20 & 4.40 & 2.00 & 7.60 \\
3. & S003 & 3.00 & 3.00 & 1.60 & 7.60 \\
4. & S004 & 2.40 & 4.70 & 1.20 & 8.30 \\
5. & S005 & 1.80 & 4.20 & 0.80 & 6.80 \\
6. & S006 & 1.80 & 3.90 & 2.00 & 7.70 \\
\hline
\end{tabular}

\subsection{Perancangan Sistem}

Adapun identifikasi kebutuhan fungsionalitas sistem penunjang keputusan untuk menentukan jurusan calon siswa dibuat menggunakan model UML use case diagram. Terdapat use case diagram yang terbagi dalam 3 bagian yaitu input, proses, dan laporan yang ditampilkan pada gambar 5, 6 dan 7. Pada gambar 5 yaitu use case diagram master yang terdiri atas : entry data siswa, entry data jurusan, entry data kriteria dan entry data profile jurusan. Pada gambar 6 yaitu use case diagram proses, yang terdiri atas : entry nilai siswa, proses perhitungan profile matching dan penetapan jurusan. Sedangkan pada gambar 7, yaitu use case diagram laporan, terdiri atas : cetak laporan hasil nilai siswa dan cetak laporan hasil pemilihan jurusan.
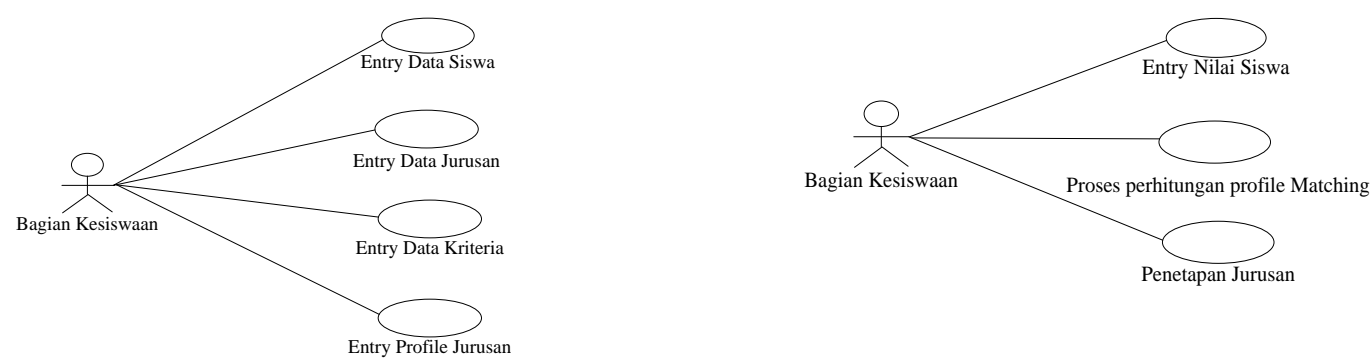

Gambar 5. Use Case Diagram Master

Gambar 6. Use Case Diagram Proses

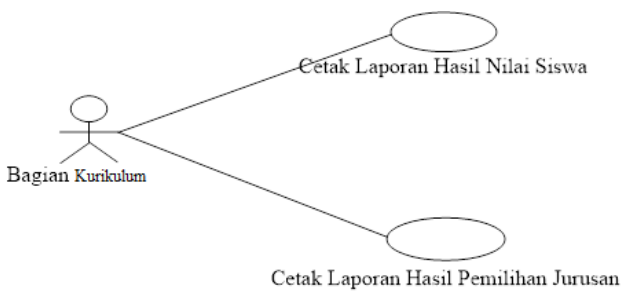

Gambar 7. Use Case Diagram Laporan

\subsection{Perancangan Basis Data}

Berdasarkan hasil identifikasi kebutuhan fungsionalitas diatas, maka berikut ini adalah model domain data yang dibutuhkan untuk mendukung sistem penunjang keputusan pemilihan jurusan calon siswa. Adapun pemodelan basis data digambarkan menggunakan model Entity Relationship Diagram. Perancangan model basis data 
JURNAL MEDIA INFORMATIKA BUDIDARMA

Volume 5, Nomor 1, Januari 2021, Page 108-123

ISSN 2614-5278 (media cetak), ISSN 2548-8368 (media online)

Available Online at https://ejurnal.stmik-budidarma.ac.id/index.php/mib

DOI 10.30865/mib.v5i1.2274

dengan Entity Relationship Diagram (ERD). ERD adalah teknik yang digunakan untuk memodelkan kebutuhan data dari suatu organisasi [13]. Adapun model kebutuhan data pada penelitian ini dijelaskan pada gambar 8.

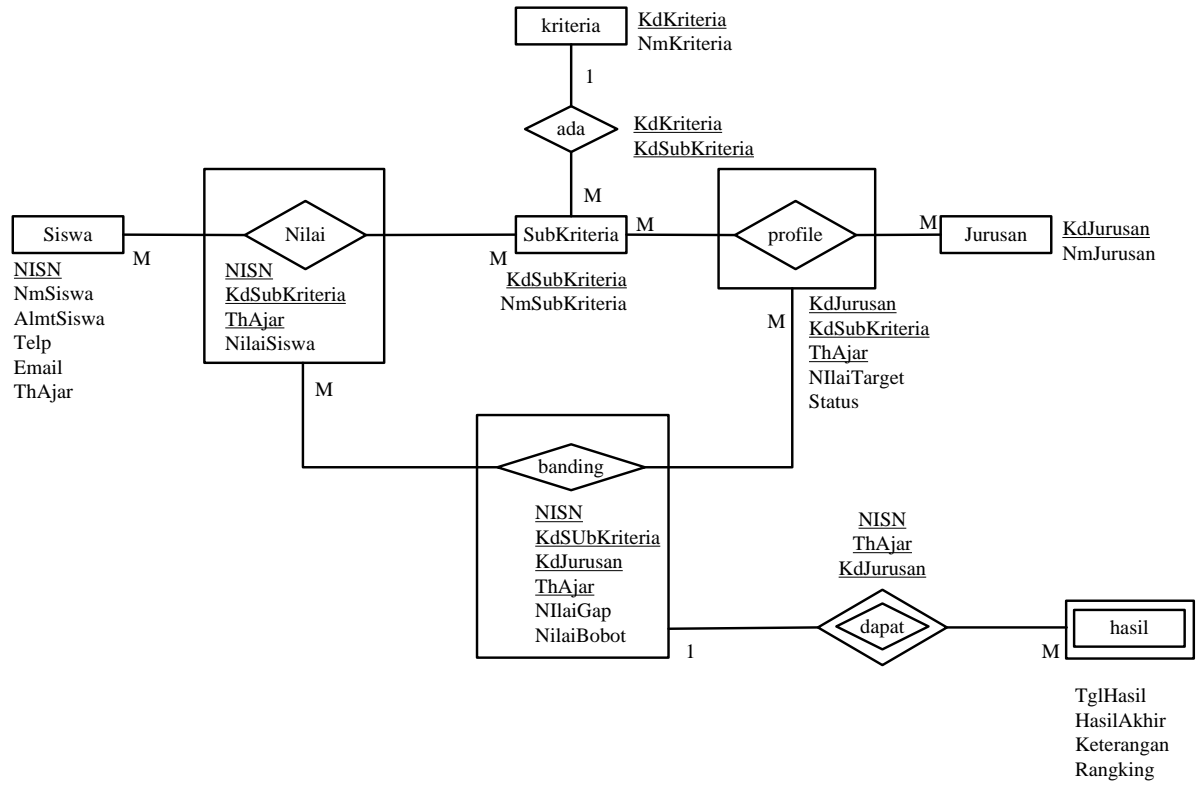

Gambar 8. Model Basis Data Dengan Entity Relationship Diagram

Terdapat 8 (delapan) entitas yang dibutuhkan, yaitu : entitas siswa, entitas kriteria, entitas subkriteria, entitas jurusan, entitas profile, entitas nilai, entitas banding dan entitas hasil.

\subsection{Rancangan Tampilan Antar Muka Pengguna (User Interface)}

Pada menu utama tersedia pilihan Input Proses, dan Laporan. Pada menu Input terdapat submenu entry data siswa, entry data jurusan, entry data kriteria, entry data subkriteria, dan entry profile jurusan. Pada menu Proses terdapat submenu entry nilai siswa, proses perhitungan Profile Matching dan Penentuan Jurusan. Pada menu Laporan terdapat submenu cetak laporan hasil nilai dan cetak laporan hasil pemilihan jurusan seperti pada gambar 9.

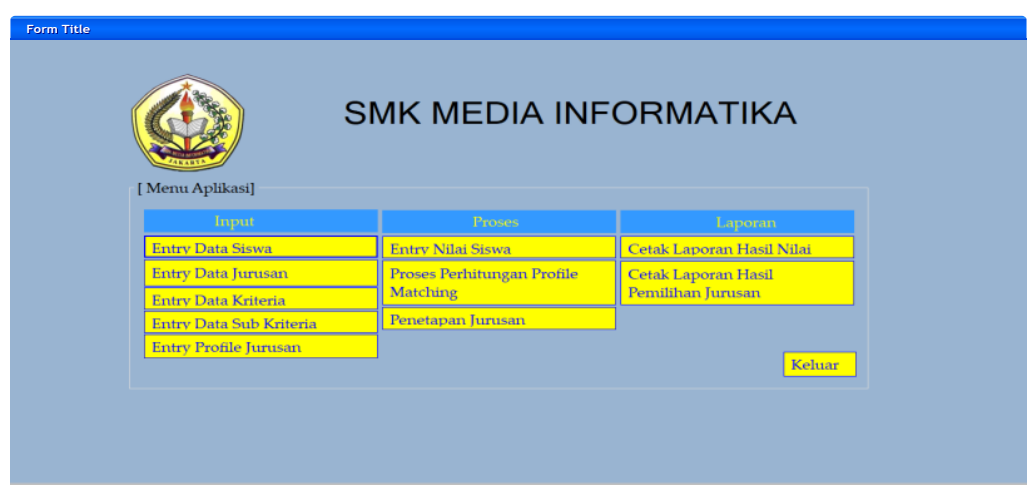

Gambar 9. Rancangan Layar Menu Utama

\subsection{Implementasi Sistem Penunjang Keputusan Pemilihan Jurusan}

Dalam penelitian ini, peneliti menggunakan bahasa pemrograman Microsoft Visual Basic 2008 dan database MySQL. Microsoft Visual Basic 2008 adalah bahasa pemrograman dengan konsep Integrated Development Environmet (IDE) visual untuk membangun aplikasi perangkat lunak berbasis operasi Windows menggunakan pemrograman COM [14]. MySQL adalah perangkat lunak database berbasis Relational Database Management System (RDBMS) untuk mengelola database dengan cepat, menampung dalam jumlah sangat besar dan dapat diakses oleh banyak pengguna [15].

\subsubsection{Antar Muka Pengguna Form Entry Data Nilai Calon Siswa}

Pada menu Input pilih submenu entry data calon siswa yang dapat digunakan untuk memasukan identitas calon siswa peserta didik baru seperti pada gambar 10 . 
JURNAL MEDIA INFORMATIKA BUDIDARMA

Volume 5, Nomor 1, Januari 2021, Page 108-123

ISSN 2614-5278 (media cetak), ISSN 2548-8368 (media online)

Available Online at https://ejurnal.stmik-budidarma.ac.id/index.php/mib

DOI 10.30865/mib.v5i1.2274

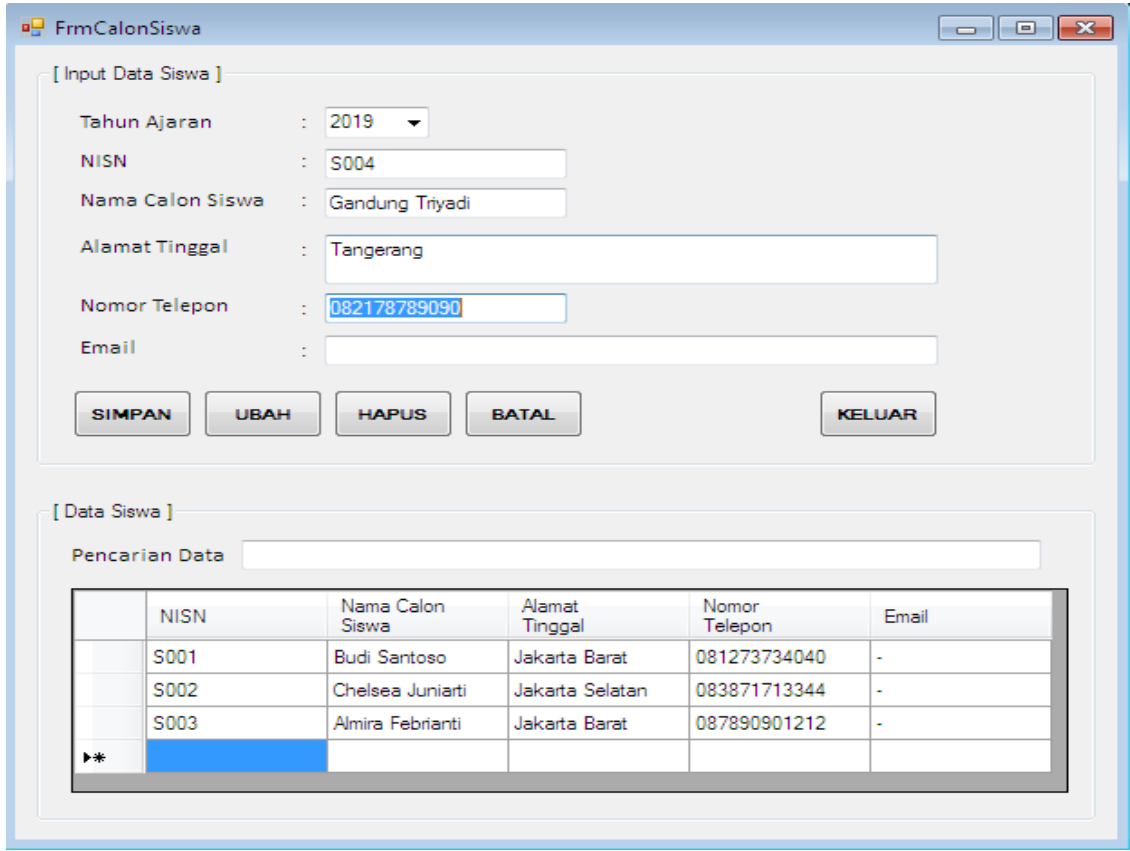

Gambar 10. Form Data Calon Siswa

\subsubsection{Rancangan Layar Entry Data Nilai Calon Siswa}

Pada menu Proses, terdapat pilihan submenu data nilai untuk menginput nilai sub kriteria dari setiap calon siswa yang ada dari masing-masing jurusan seperti pada gambar 11.

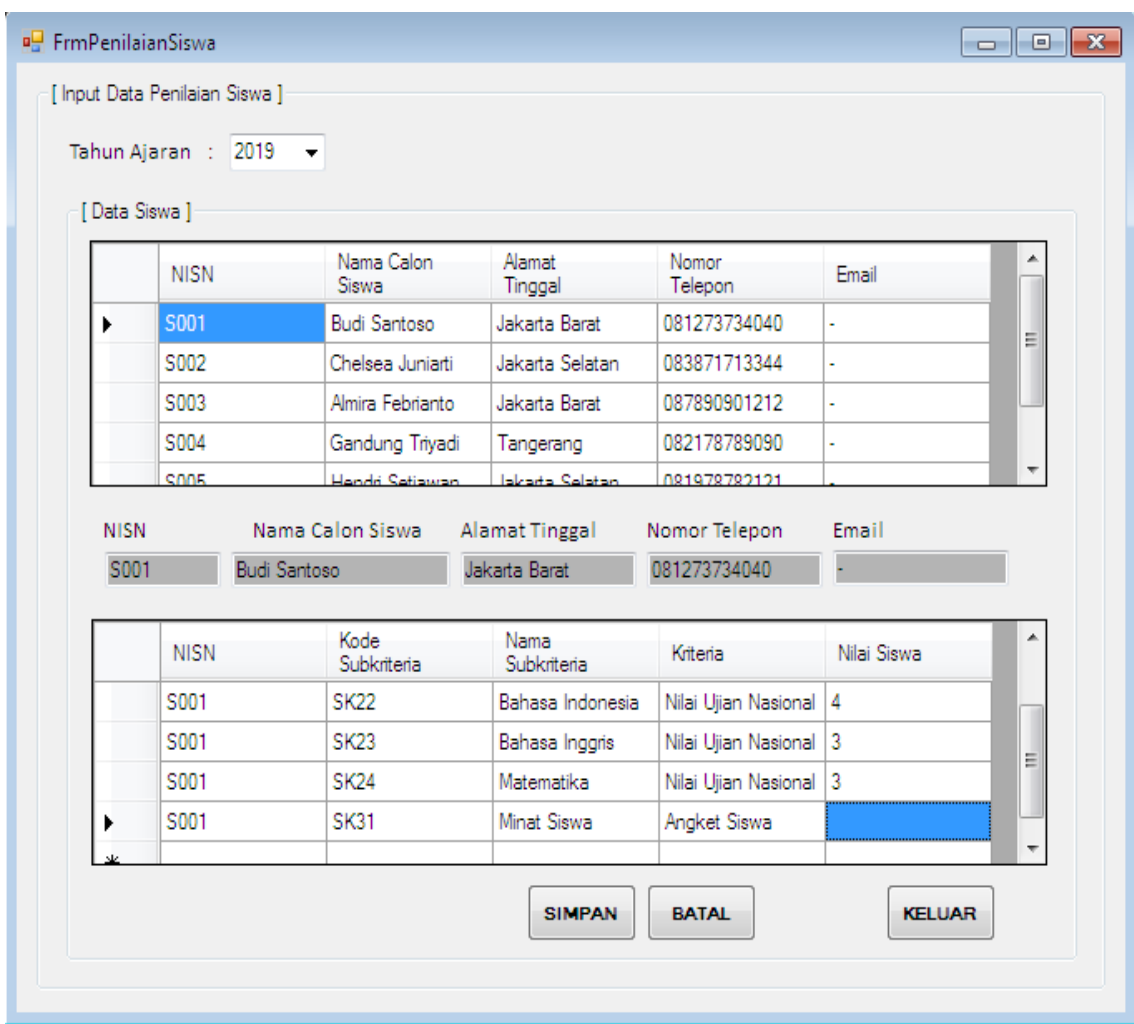

Gambar 11. Form Entry Nilai Calon Siswa

\subsubsection{Proses Perhitungan Nilai dengan Metode Profile Matching}

Pada form ini memberikan informasi perhitungan matematis menggunakan metode profile matching, yang memiliki empat tabular yaitu tab perhitungan penetapan gap, pembobotan nilai gap, perhitungan factor dan nilai akhir/total. Tab perhitungan gap digunakan untuk menghitung selisih antara nilai target per kriteria masingmasing jurusan dan nilai hasil konversi dari masing-masing calon peserta didik baru. Adapun tab perhitungan penetapan gap seperti yang ditampilkan pada gambar 12 . 
JURNAL MEDIA INFORMATIKA BUDIDARMA

Volume 5, Nomor 1, Januari 2021, Page 108-123

ISSN 2614-5278 (media cetak), ISSN 2548-8368 (media online)

Available Online at https://ejurnal.stmik-budidarma.ac.id/index.php/mib

DOI 10.30865/mib.v5i1.2274

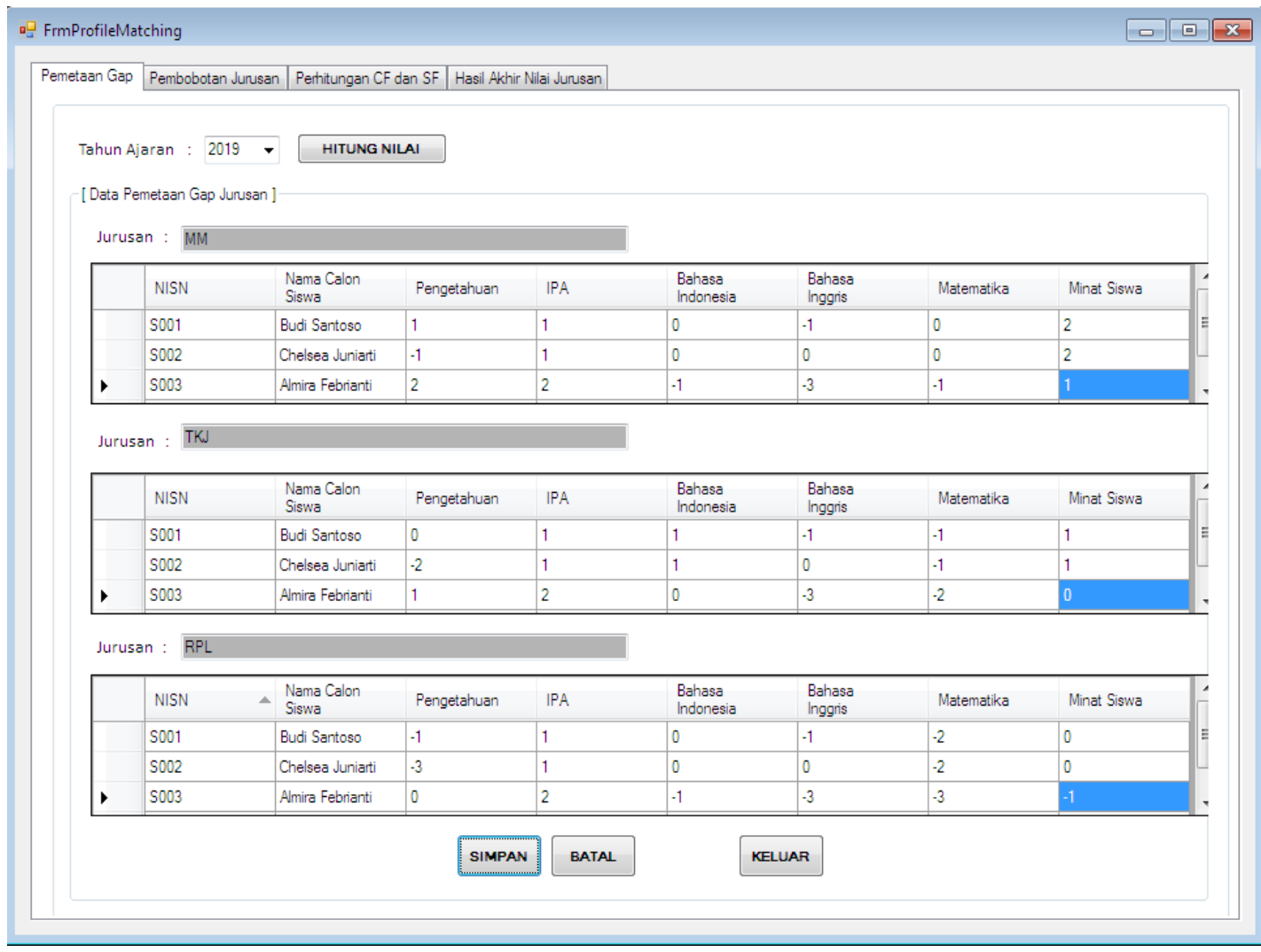

Gambar 12. Form Perhitungan Penetapan Gap

Berikutnya adalah menghitung pembobotan nilai gap per alternatif untuk setiap jurusan. Adapun tab pembobotan nilai gap seperti yang ditampilkan pada gambar 13.

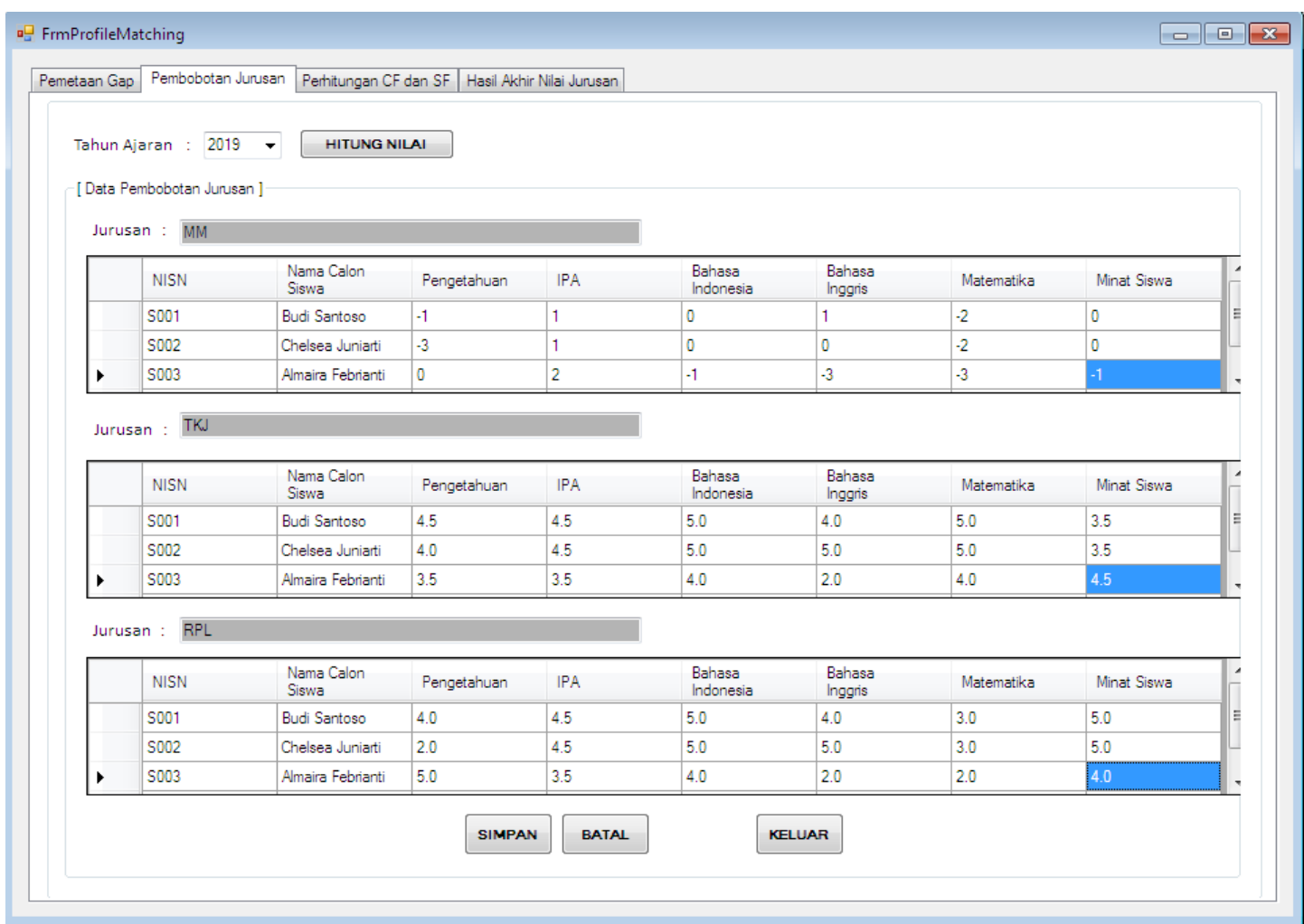

Gambar 13. Form Perhitungan Pembobotan Nilai Gap

Berikutnya adalah menghitung nilai Core Factor $(\mathrm{CF})$ dan Secondary Factor (SF) untuk setiap alternatif per jurusan. Adapun tab perhitungan Core Factor $(C F)$ dan Secondary Factor $(S F)$ seperti yang ditampilkan pada gambar 14. 
JURNAL MEDIA INFORMATIKA BUDIDARMA

Volume 5, Nomor 1, Januari 2021, Page 108-123

ISSN 2614-5278 (media cetak), ISSN 2548-8368 (media online)

Available Online at https://ejurnal.stmik-budidarma.ac.id/index.php/mib

DOI 10.30865/mib.v5i1.2274

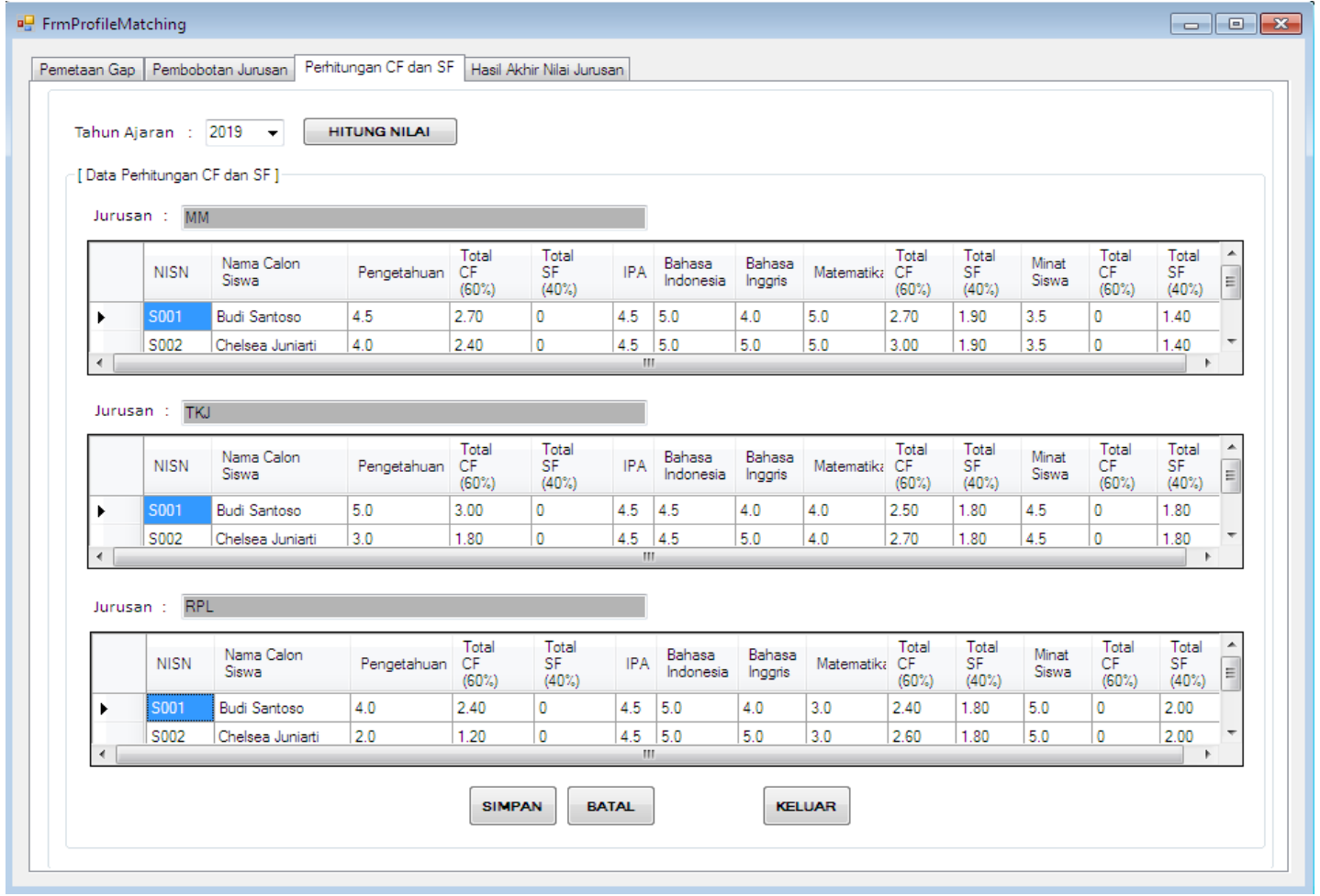

Gambar 14. Form Perhitungan Core Factor (CF) dan Secondary Factor (SF)

Dalam gambar 14 diatas, kolom Total SF (40\%) pada sub kriteria Pengetahuan dan total SF pada sub kriteria Minat Siswa tidak digunakan sesuai dengan tabel 2,3,4 sehingga nilai Total SF pada kedua atribut tersebut bernilai 0 . Berikutnya adalah menghitung nilai akhir atau total nilai untuk setiap alternatif per jurusan. Adapun tab perhitungan nilai akhir / total nilai seperti yang ditampilkan pada gambar 15 .

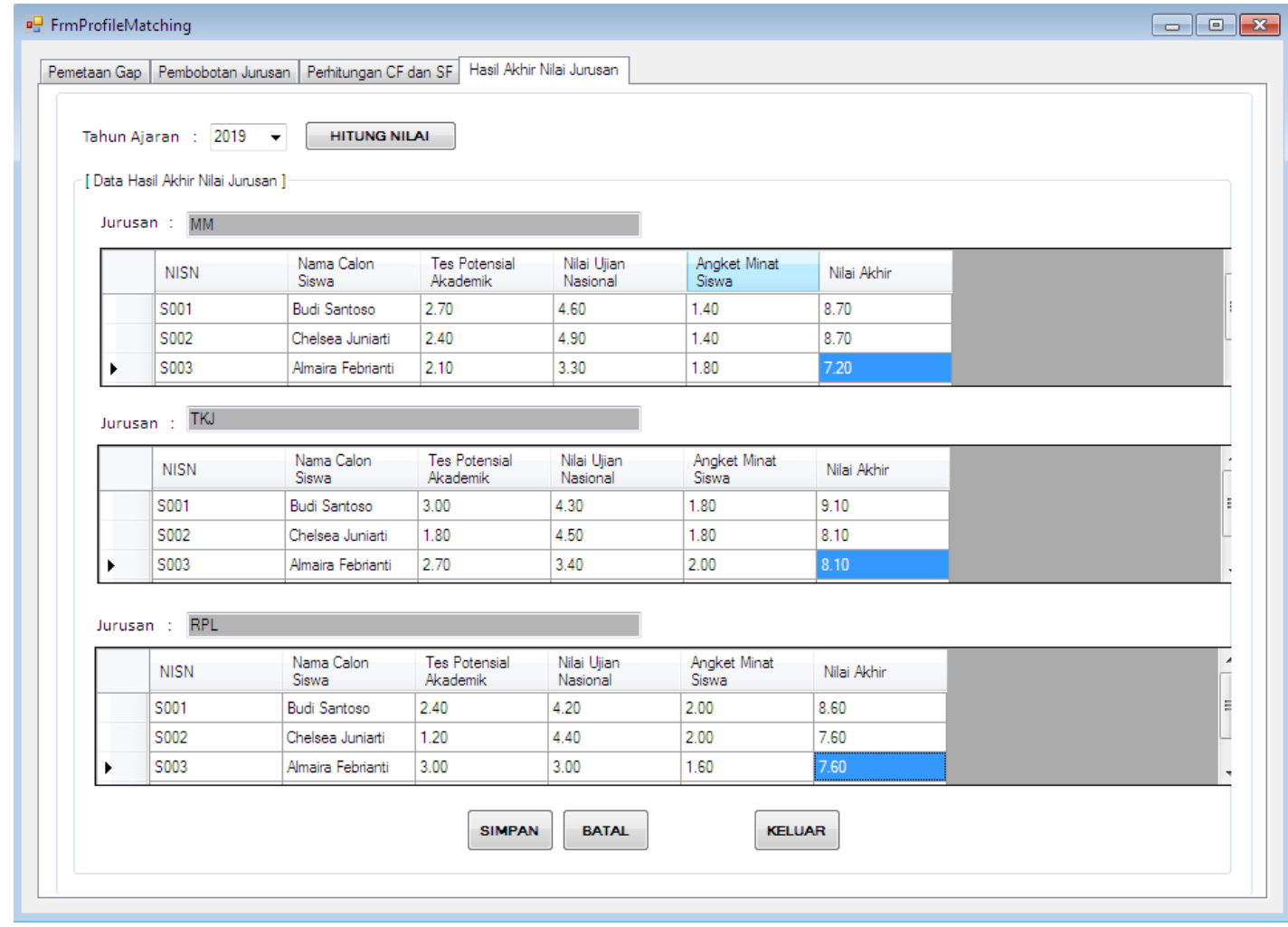

Gambar 15. Form Perhitungan Nilai Akhir Per Jurusan

Pada gambar 15 diatas, nilai akhir setiap alternatif untuk setiap jurusan diperoleh dengan menambahkan nilai Tes Potensial Akademik dengan nilai Ujian Nasional dan nilai Angket Minat Siswa. 
ISSN 2614-5278 (media cetak), ISSN 2548-8368 (media online)

Available Online at https://ejurnal.stmik-budidarma.ac.id/index.php/mib DOI 10.30865/mib.v5i1.2274

\subsubsection{Antar Muka Pengguna Form Rekomendasi Pemilihan Jurusan}

Pada menu Form Penetapan Jurusan untuk membuat cetakan hasil rekomendasi pemilihan jurusan calon siswa seperti yang ditampilkan pada gambar 16.

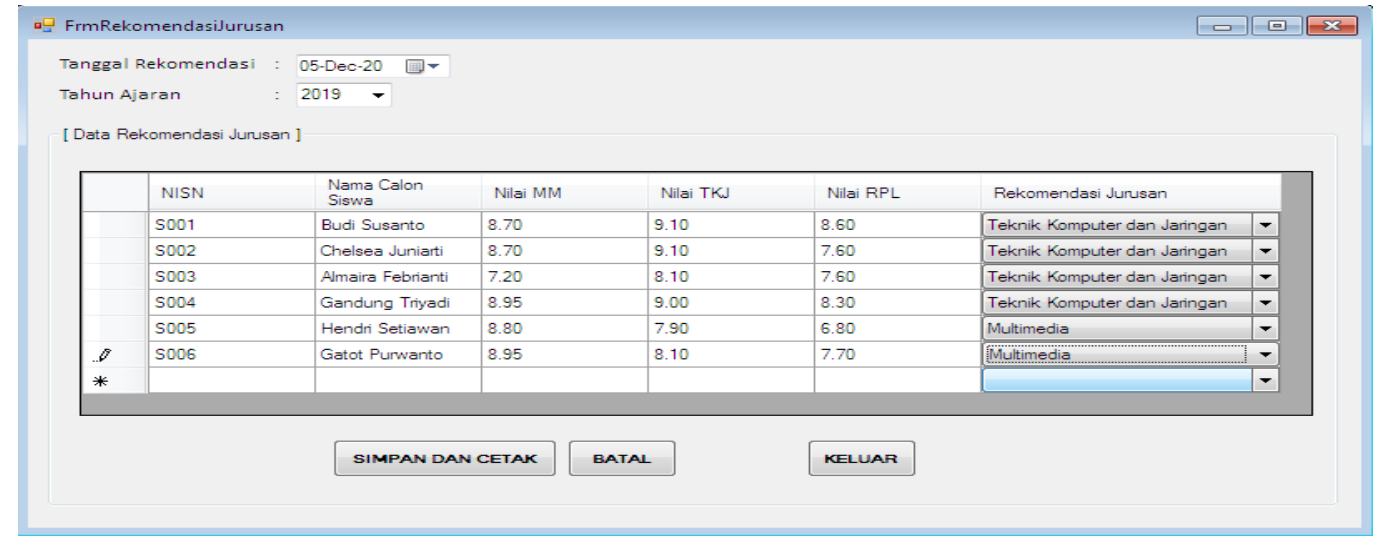

Gambar 16. Form Rekomendasi Pemilihan Jurusan

Pada gambar 16 diatas, pengguna sistem dapat melihat informasi nilai MM, nilai TKJ dan Nilai RPL, kemudian dibandingkan manakah nilai yang terbesar dari ketiga nilai tersebut untuk menentukan rekomendasi jurusan pada calon siswa. Adapun hasil keluaran laporan rekomendasi pemilihan jurusan calon siswa seperti yang ditampilkan pada gambar 17.

\begin{tabular}{|c|c|c|c|c|}
\hline & \multicolumn{2}{|c|}{$\begin{array}{l}\text { SEKOLAH MENENGAH KEJL } \\
\text { SMK MEDIA INFORMATIKA }\end{array}$} & $\begin{array}{l}\text { elatan Pesa } \\
\text { mediainforn }\end{array}$ & $\begin{array}{l}\text { rahan Jakarta Selatan Jakarta } 12270 \\
\text { a. sch.id }\end{array}$ \\
\hline \multicolumn{5}{|c|}{$\begin{array}{l}\text { LAPORAN HASIL REKOMENDASI PEMILIHAN JURUSAN CALON SISWA } \\
\text { TAHUN AJARAN : } 2019 / 2020\end{array}$} \\
\hline No. & NISN & Nama Calon Siswa & Nilai Akhir & Jurusan \\
\hline 1. & S001 & Budi Susanto & 9.10 & Teknik Komputer dan Jaringan \\
\hline 2. & $\mathrm{~S} 002$ & Chelsea Junianti & 9.10 & Teknik Komputer dan Jaringan \\
\hline 3. & $\mathrm{~S} 003$ & Almaira Fe brianti & 8.10 & Teknik Komputer dan Jaringan \\
\hline 4. & $\mathrm{~S} 004$ & Gandung Triy adi & 9.00 & Teknik Komputer dan Jaringan \\
\hline 5. & S005 & Hendri Setiawan & 8.80 & Multime dia \\
\hline 6. & S006 & Gatot Purwanto & 8.95 & Multime dia \\
\hline
\end{tabular}

Jakarta, 30 Juni 2019

Kepala Bagian Kesiswaan

Gambar 17. Keluaran Laporan Hasil Rekomendasi Pemilihan Jurusan Calon Siswa

Gambar 17 diatas merupakan contoh keluaran hasil rekomendasi pemilihan jurusan untuk setiap calon siswa. Hasil tersebut belum bersifat final, karena masih harus didiskusikan dengan calon siswa terkait, apakah akan menerima atau tidak hasil rekomendasi jurusan yang diberikan.

\section{KESIMPULAN}

Berdasarkan analisa dan perancangan sistem penunjang keputusan untuk menentukan jurusan calon peserta didik baru pada SMK XYZ, maka dari itu dapat ditarik kesimpulan sebagai berikut : aplikasi sistem penunjang keputusan ini dapat membantu bagian kesiswaan dalam menentukan keputusan penjurusan kepada calon siswa baru dengan lebih akurat, staf kesiswaan dapat mencocokkan profil siswa dengan profil jurusan sehingga siswa akan merasa cocok antara jurusan dan kemampuannya, dengan adaya fitur proses perhitungan profile matching dan pembobotan kriteria penilaian, maka pengolahan data penilaian menjadi lebih cepat sehingga hasil rekomendasi jurusan dengan cepat diberikan kepada calon siswa, dan dengan adanya rekomendasi pemilihan jurusan calon siswa yang tepat, maka dapat meminimalkan terjadinya pindah jurusan. 
JURNAL MEDIA INFORMATIKA BUDIDARMA

Volume 5, Nomor 1, Januari 2021, Page 108-123

ISSN 2614-5278 (media cetak), ISSN 2548-8368 (media online)

Available Online at https://ejurnal.stmik-budidarma.ac.id/index.php/mib DOI 10.30865/mib.v5i1.2274

\section{REFERENCES}

[1] E. Faizal, "Implementasi Metode Profile matching untuk Penentuan Penerimaan Usulan Penelitian Internal Dosen STMIK El Rahma," Speed-Sentra Penelit. Eng. dan Edukasi, vol. 6, no. 1, pp. 60-65, 2014.

[2] Kusrini, Konsep dan Aplikasi Sistem Penunjang Keputusan. Yogyakarta: Andi Press, 2007.

[3] Andi Mappiare, Psikologi Remaja, Usaha Nasi. Surabaya, 1982.

[4] A. Rustiawan, Asep Hendar, Destiani, Dini dan Ikhwana, "Sistem Penunjang Keputusan Penyeleksian Calon Siswa Baru di SMA Negeri 3 Garut," J. Algoritm., vol. 09(20), 2012.

[5] M. Raihan, F. Fitriyadi, and S. Abidah, "Penerapan Metode Profile Matching Pada Proses Pemilihan Lokasi Perumahan," Jutisi J. Ilm. ..., pp. 827-836, 2016, [Online]. Available: http://ojs.stmikbanjarbaru.ac.id/index.php/jutisi/article/view/103.

[6] M. M. Amin and E. Cofriyanti, "Sistem Rekomendasi Pemilihan Kandidat Calon Tenaga Kerja Menggunakan Model Profile Matching," Pros. SINTAK, pp. 108-115, 2017.

[7] L. Tanti, "Analisis Promosi Kenaikan Jabatan Berdasarkan Evaluasi Kinerja Pegawai," Creat. Inf. Technol. J., vol. 3 , no. 4, p. 331, 2016, doi: 10.24076/citec.2016v3i4.88.

[8] P. Yw and A. Muhajirien, "Sistem Pendukung Keputusan Promosi Jabatan Karyawan Menggunakan Metode SimpleAdditive Weighting ( SAW )," vol. 1, no. 1, pp. 94-108, 2016

[9] D. Turban, Efram, Decision Support System and Intelligent System. Yogyakarta: Andi Press, 2005.

[10] L. D. Whitten, Jeffrey L and Bentley, System Analysis and Design for the Global Enterprise. McGraw Hill, 2004

[11] I. P. A. E. Pratama, Sistem Informasi dan Implementasinya., Ist Editio. Bandung: Informatika, 2014.

[12] C. N. Ciocoiu, "Application of Fishbone Diagram To Determine the Risk of an Event With Multiple Causes," Manag. Res. Pract., vol. 2, no. 1, pp. 1-20, 2010.

[13] J. Brady, M and Loonam, Exploring the use of entity-relationship diagramming as a technique to support grounded theory inquery. Bradford: Emerald Group, 2010.

[14] Stefano, Cara Membangun Sistem Informasi Menggunakan VB.Net dan Komponen Dxperience. Yogyakarta: Andi Press, 2014.

[15] B. Raharjo, Belajar Otodidak Membuat Database Menggunakan MySQL. Bandung: Informatika, 2011. 